\title{
Fundamentals and Advances in Elastohydrodynamics: The Role of Ramsey Gohar
}

\author{
Patricia M. Johns-Rahnejat ${ }^{1, * \mathbb{D}}$, Ghodrat Karami ${ }^{2}$, Reza Aini ${ }^{3}$ and Homer Rahnejat ${ }^{1}$ \\ 1 The School of Engineering, University of Central Lancashire, Preston PR1 2HE, UK; hrahnejat@uclan.ac.uk \\ 2 Department of Mechanical Engineering, North Dakota State University, Fargo, ND 58104, USA; \\ g.karami@ndsu.edu \\ 3 SharkNinja Ltd., London SW1V 1HU, UK; reza.aini@ymail.com \\ * Correspondence: pjohns-rahnejat@uclan.ac.uk
}

check for

updates

Citation: Johns-Rahnejat, P.M.; Karami, G.; Aini, R.; Rahnejat, H. Fundamentals and Advances in Elastohydrodynamics: The Role of Ramsey Gohar. Lubricants 2021, 9, 120. https://doi.org/10.3390/

lubricants 9120120

Received: 27 October 2021

Accepted: 3 December 2021

Published: 8 December 2021

Publisher's Note: MDPI stays neutral with regard to jurisdictional claims in published maps and institutional affiliations.

Copyright: () 2021 by the authors. Licensee MDPI, Basel, Switzerland. This article is an open access article distributed under the terms and conditions of the Creative Commons Attribution (CC BY) license (https:// creativecommons.org/licenses/by/ $4.0 /)$.

\begin{abstract}
This paper commemorates Ramsey Gohar by acknowledging his contributions to the fields of contact mechanics and elastohydrodynamic lubrication (EHL) within the context of the developments of these subjects. A historical discourse is provided on elastohydrodynamics, from its inception in the 1940s to present. We demonstrate that Ramsey Gohar was not only a pioneer in the discoveries and fundamentals of the subject, but also led or contributed significantly to continual advances in the understanding of EHL and its diverse applications.
\end{abstract}

Keywords: contact mechanics; elastohydrodynamic lubrication; ball and rolling element bearings; Ramsey Gohar

\section{Introduction}

Dr. Ramsey Gohar was one of the pioneers in the field of elastohydrodynamic lubrication (EHL). After obtaining his bachelor's degree in Mechanical Engineering in 1951, Ramsey spent time in the industry, working on an assortment of industrial lubrication problems. From his time at D. Napier \& Son, manufacturers of aircraft, automotive and marine engines (Figure 1), he attained valuable practical experience in contact mechanics and lubrication. In the late 1950s, Ramsey worked on gyroscopes in the research laboratories of General Electric, which inspired his lifelong interest in rigid body dynamics. His association with the Lubrication Laboratory at Imperial College led to his MSc dissertation in 1959 on the lubricated contact of ellipsoidal solids of revolution [1]. This dissertation was very timely, as research on elastohydrodynamic lubrication was still in its infancy.

Since the publication of Osborne Reynolds' theory of hydrodynamic lubrication [2], the absence of wear in contacts with hydrodynamic films of seemingly insufficient thickness [3] had been puzzling. There were many suppositions for the apparent increased load carrying capacity of the lubricant film separating the contiguous surfaces. These included the piezoviscous effect of the lubricant under increased pressures [4,5] and the localised deformation of surfaces based on the Hertzian contact theory, proposed by Ertel and Grubin [6-8]. Ramsey's MSc and subsequent research led to his seminal contributions to the fields of contact mechanics and elastohydrodynamic lubrication. 


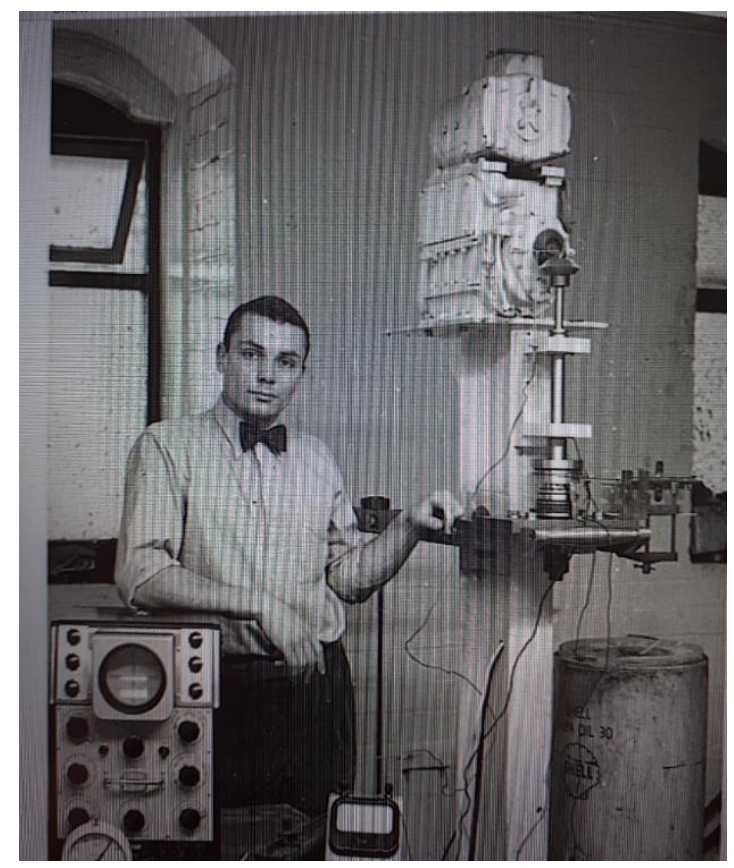

Figure 1. Ramsey Gohar in front of an engine test-rig in 1959 [1].

\section{Fundamentals of Elastohydrodynamic Lubrication}

Throughout his 60-year research career, Ramsey contributed to the understanding of the fundamentals of fluid-film lubrication, by developing means of observation, precision measurement techniques and numerical and analytical methods of prediction. He published numerous outstanding contributions, only a sample of which are highlighted here within the context of developments in elastohydrodynamic lubrication, and its application to concentrated contacts, particularly in bearings.

\subsection{Observation and Measurements of Elastohydrodynamic Conditions}

A fundamental understanding of any phenomenon requires careful observations and precise measurements. The development of EHL theory and predictive methods is no exception. Ramsey provided some pioneering contributions in this regard. His $\mathrm{PhD}$ research contributed significantly to both measurements and theoretical developments in EHL [9].

Following early works on EHL [6-8], Petrusevich included both the effect of lubricant piezoviscous behaviour, and localised elastic deformation of surfaces [10]. A first iterative numerical solution was provided by Dowson and Higginson [11] for the case of EHL of line contacts. The predictions obtained in [11] were confirmed using capacitive measurement of the thin lubricant films by Crook [12], and by Sibley and Orcutt using an X-ray technique [13]. Other early solutions include [14,15]. Brief historical accounts of these solutions are provided in [16,17].

By the early 1960s, it had become clear that both iterative numerical solutions and methods of observation and measurement were much more complicated for the general case of a lubricated concentrated elliptical point contact than for a line contact. Thus, Ramsey directed his research towards the numerical solution of point contact EHL and its verification, through observation and precise measurements. This work culminated in his $\mathrm{PhD}$ thesis [9].

Regarding observations and measurement of film thickness, Shultz [18] had already reported an interferometric method for very thin evaporated films. This method was improved by Tolansky [19] and used by Kirk [20] for hydrodynamic films between a pair of crossed perspex cylinders. Kirk [20] noted the importance of direct observation of lubricated contacts using transparent contacting bodies that form fringes to measure 
lubricant film thickness. Shortly afterwards, some of the interferometric results of EHL of circular point contact for a rotating ball against a flat glass disc from Ramsey's research were published [21]. Detailed optical interferometric studies of EHL contacts was born with this seminal contribution. In time, the interferometric and spectroscopic methods of measurements of lubricant films improved the use of colour fringes, and led to the inclusion of spacer layers in glass races to measure ultra-thin films. The literature describing various conditions and applications includes [22-25]. An optical interferometric study for endclosure films in finite line contact of roller-to-races was initially presented by Gohar and Cameron [26], Bahadoran and Gohar [27], and Wymer and Cameron [28]. More recent interferometric studies of various EHL contact conjunctions were reported in [29-32].

The measurement of elastohydrodynamic conditions was promoted with the development of deposited miniature micro-transducers in the tiny footprint areas of concentrated contacts. Initially, these transducers were typically a few hundred micrometres in dimension with a thickness of the order of a few hundred Angstroms. Therefore, they did not significantly affect the contact conditions. They were capacitive or pressure-sensitive in nature, measuring lubricant film thickness of the order of a few tenths of a micrometre or high pressures of a few giga-Pascals.

Whilst optical interferometry proved to be the most established and refined method of obtaining interferograms of lubricated contacts and the lubricant film thickness, the measurement of high contact pressures under EHL was a much tougher proposition. The measurement of high pressures in minute contact conjunctions received an impetus with the pioneering work of Bridgman [33], using pressure sensitive bulk manganin with low temperature sensitivity. Later, bulk manganin powder was deposited using a flash-evaporation technique to form ultra-thin pressure sensitive transducers in EHL contacts $[34,35]$. The preliminary results were fitted rather crudely to calculate Hertzian pressure profiles, as the centre of contact pressure distribution could not be precisely ascertained in the measurements. Nevertheless, a new precise method of measurement of high elastohydrodynamic pressures had now been established. At this stage the transducer width was of the order of several hundred micrometres, so further refinements were required to resolve the important EHL contact features, such as the exit pressure spike. Kannel [36], Hamilton and Moore [37] fabricated micro-transducers that were capable of monitoring EHL pressures in line-contact conditions when deposited on a disc in a disc machine. Significantly improved manganin micro-transducers with active element dimensions of $5 \times 10 \mu \mathrm{m}^{2}$ and thickness between 100-300 $\AA$ were developed through RF sputtering of bulk manganin powder, under high vacuum at Imperial College. They were used for line contact conditions in roller bearings or in a disc machine [38-41]. More importantly, they were employed for the circular-point contact of a ball on a flat glass race in pure rolling [42,43], as well as for a sphere impacting and rebounding on an oily plate [44]. The ultra-thin active element of the micro-transducer allowed for the precise resolution of the EHL pressure spike, which had eluded all methods of measurement thus far. These precise measurements later allowed for the verification of highly improved and detailed numerical analyses, such as those presented by Gohar and his co-workers [45].

\subsection{Numerical Predictions of Contact Mechanics and Elastohydrodynamic Lubrication 2.2.1. Elliptical Point Contacts}

Another ground-breaking contribution from Ramsey was the development of an iterative numerical method for the prediction of the point contact EHL problem [46], which was part of his doctoral research [9]. This was the first general solution of 2D-point contact EHL, and paved the way for the development of many other solutions. The most notable include those of Hamrock and Dowson [47-50], who considered various inlet boundary conditions; flooded or starved, as well as the contact footprint aspect ratio for elliptical point contacts. Vakilzadeh and Gohar [51] presented predictions for circular point contact EHL with inlet starvation. Thorp and Gohar [24] and Mostofi and Gohar [52] considered the general case of elliptical point contacts with angled inlet flow into the contact, a condition 
which occurs in rolling and sliding contacts such as in hypoid gear teeth meshing. Other solutions for angled inlet flow into the contact conjunction were provided by Chittenden et al. [53,54], and Evans and Snidle [55], who also presented an inverse method to solve EHL conditions at high loads [56]. Other early solutions include EHL of contacts of low elastic modulus [57-59] as well as EHL of wavy or rough surfaces [60-64].

Since the proposal of the aforementioned numerical EHL solutions, there have been improvements in the methods of discretisation of the computational domain and iterative procedures, particularly under transient conditions. Ramsey contributed to the earlier developments of these methods, including the use of low-relaxation effective influence Newton-Raphson method [65-67] and multi-grid techniques [68-71]. Detailed analyses of EHL contacts under steady state and transient conditions with various formulation and solution methods were provided comprehensively by Ramsey [72,73]. He verified his various solutions for the EHL of circular $[9,21,69]$ and elliptical $[24,66]$ point contacts with his earlier optical interferometric studies. Other recent solutions have also used Ramsey's optical interferometric studies for circular point contacts and for elliptical point contacts with rolling and sliding pairs with angled inlet flow conditions [74]. Ramsey's measurements of the lubricated impact of a sphere [44] have also been used to validate predictive transient EHL analyses [75]. Since then, many solutions have been proposed for the EHL of point contacts across various applications, such as bearings and gears under transient, thermal and non-Newtonian conditions. They include those described in [16,72-85]. Some researchers have employed alternative methods of formulation and solution, including finite elements, the complementarity approach or computational fluid dynamics (CFD) [86-89], including an early contribution by Ramsey and his co-workers [90].

\subsubsection{Finite Line Contacts}

Original solutions of EHL problems proposed the lubrication of rollers and involute spur gears at high loads. The contact footprint for these conditions is a thin rectangular strip with very large length-to-width ratio. Therefore, an infinite line contact was initially considered for contact mechanics analyses by Hertz [91], with an elliptical pressure distribution along the width of the contact and a uniform pressure along its length. However, it became immediately clear that, because the actual length of the contact is finite and, because there are abrupt changes at the edges of a roller profile, edge stress discontinuities occur. This leads to the generation of high pressures in these regions, reducing the fatigue life of such contacts, not initially considered in bearing-design analysis, based on Hertzian predictions [92]. Clearly, the axial profile of finite length bodies in contact, such as rollers in bearings, affects the generated pressures as does any misalignment. This was already noted by Palmgren [93]. Lundberg [94] discussed the effect of axial profile of rollers on generated pressures in finite line contact, pointing to pressure spikes at the edge of the contact, which may be reduced by form-relieving. The ideal axial profile is composed of a series of intersecting logarithmic curves. Earlier numerical analyses of finite line contacts provided solutions of a boundary integral equation, relating the generated pressures to the localised deformation of contacting surfaces under load, by assembling a matrix of influence coefficients $[95,96]$. Ramsey engaged in sustained research regarding contact mechanics of cylindrical rollers with different axial profiles, using finite difference discretisation techniques, including arithmetic, geometric and singularity elements to accurately predict edge stress discontinuities [97-100]. He also dealt with complex direct and moment loading conditions [101,102]. In addition, Ramsey extended his contact mechanics studies to the case of tapered roller bearings under complex loading [103,104]. A brief review of contact mechanics analysis, under elastostatic conditions, from semi-infinite to the case of bonded, layered solids (such as coatings) is provided in [105].

With his extensive contribution to contact mechanics during 1959-1977, Ramsey was regarded as the leading analyst in ball and rolling element bearing analysis, culminating in the presentation of optimal design criteria for rolling elements in a seminal paper in the New Scientist [106]. Incidentally, this contribution makes Ramsey Gohar the rara avis 
of his generation of tribologists, having published not only in Nature, but in Proceedings of the Royal Society as well as in the New Scientist; such was the quality of his seminal contributions.

Ramsey continued his research into the mechanics of finite line contacts by studying their EHL. His work included optical interferometric studies of rollers [27], and the first ever measurement of pressure between a roller and a plate in relative motion, using a pressure transducer mounted in a hole filled by lubricant [107]. These were conducted prior to the measurement of pressure in a disc machine, using a micro-miniature transducer [41]. His initial numerical prediction of the EHL of finite line contact was included in a research note, in collaboration with Bahadoran [108], describing an approximate theory to determine the shape of the surfaces at the end-closure of contact of profiled rollers. His research in finite line EHL concentrated on the effect of the roller axial profile on the generated high pressures at the contact extremities, as well as the absolute minimum film thickness at these extremities, termed as the side exit lubricant film thickness, which agreed well with experimental observations [109]. It was shown that under EHL conditions, the pressure spikes at the edges of the contact exceed even those under elastostatic conditions. Some explanations for this phenomenon were provided. Later, finite line elastohydrodynamics of profiled rollers under aligned and misaligned conditions were studied in detail and were in good agreement with experimental optical interferometric studies [110]. This work was extended to cam-tappet contact [111] and rollers-to-races contacts in bearings, with the rollers subjected to combined rolling, tilting and squeeze-film motions under transient conditions [112].

Since the earlier contributions by Ramsey and his co-workers, the EHL of finite line contacts occurring in many applications under various operating conditions has been studied extensively. A representative sample can be found in [113-117].

\subsubsection{Sub-Surface Stresses and Contact Fatigue}

Ramsey discussed the importance of the effect of generated pressures upon the subsurface-stress field in concentrated contacts [72,73]. These are often responsible for contact fatigue through inelastic deformation [73]. There has been a significant volume of research on sub-surface contact stresses, particularly for the case of concentrated non-conforming contacts of semi-infinite elastic solids. The first solution was provided by Huber and Fuchs [118]. For bearings and gears, Ioannides and Harris [119] pointed out that cyclic reversing orthogonal stresses often represent the limiting factor for failure. Lyman [120] was the first to study reversing orthogonal shear stresses in rolling contacts, while Poritsky [121] investigated their effect in gears and locomotive wheels. Ramsey and his co-worker, JohnsRahnejat [42,122], developed detailed models for the evaluation of three-dimensional subsurface stress fields under elastohydrodynamic point contacts. They favoured orthogonal shear stress criterion for the failure of ductile materials and the Tresca criterion for the case of hard and brittle contacting surfaces. Johnson $[123,124]$ provided a detailed review as well as the fundamentals of contact mechanics of non-conforming concentrated contacts. A more up-to-date review of predictive methods and recent contributions is provided by Sadeghi [16]. A generic semi-analytical method for all contacts of varying conformity is provided in [125], based on the general approach of Muskhelishvili [126]. The predictive contact mechanics analysis of sub-surface stress fields has received much attention. This includes cases of thin bonded or unbonded elastic or viscoelastic layers [127-129].

A novel approach was developed by Ramsey and his co-workers in representing generated contact pressures as a series of Fourier waves, applied over the contact footprint, penetrating the contacting layered bonded solids, such as coatings on an elastic substrate [130]. The resulting sub-surface stress field indicated that soft layers transmit the generated stresses into lower layers, whilst harder layers retain their effects. This approach allows for the design and fabrication of coated contacting surfaces. Clearly, thin hard bonded layers/coatings generate much higher pressures than those generated for semi-infinite solids [73,131]. 


\subsection{Tribo-Dynamics of Shaft and Bearing Systems}

Most tribologists' concerns with dynamics phenomena relate to transient conditions, as represented by the normal approach and separation of contacting surfaces (the squeeze film effect in Reynolds' equation). All other dynamics' phenomena, such as changes in applied loads in, for example, rolling elements-to-races contacts and their orbital motion into and out of the loaded zone of a bearing, are usually determined through dry contact dynamics. Then, their effect upon lubricant film thickness is measured through a subsequent lubrication analysis. This serial and non-iterative linkage between tribology and dynamics' analyses can be regarded as quasistatic in nature [73]. In reality, a combined integrated tribo-dynamic analysis is required. Ramsey was very interested in such an approach for his favoured topic of ball and rolling element bearing dynamics. He and his co-workers used extrapolated oil film thickness formulae, obtained through a regression of numerical results $[7,11,14,49,53]$. However, these formulae rarely included the effect of squeeze-film motion, and were thus not suitable for inclusion in a tribo-dynamics' analysis. This addition was provided by Mostofi and Gohar [52,132], for the case of elliptical point contacts, also including the effect of angled-flow entrainment into the contact, similar to [53]. The oil-film thickness equations for line contact geometry $[7,11]$ were extended for the realistic case of finite-line contact $[73,133]$.

Rahnejat and Gohar [73,134] re-arranged the lubricant film thickness equations to identify the relationship between the applied contact load, film thickness (gap, localised deformation and any waviness) and contact kinematics. This relationship was linked to dynamics of the system such as shaft and bearings, through applied external loading or movement of the centres of retaining shafts [134]. A step-by-step integration algorithm, such as Newmark's integration algorithm [135], was adopted to solve the tribo-dynamic equations of motion, thereby determining the transient state of contact dynamics [136]. This approach yielded the first ever solution of lubricated contact dynamics of ballsto-races contacts in orbital paths undergoing iso-viscous, piezo-viscous and EHL time histories [134]. Most contributions in shaft and bearing dynamics' problems assume dry contact conditions such as Hertzian or neo-Hertzian conditions, as evidenced in [137-141]. Such an assumption can be a good approximation for EHL contact conditions with no emerging clearances in the bearing. This approach was also used by Ramsey and his co-workers [142-146]. Although the methods of dynamics analysis and further features such as flexible multi-body analysis have emerged, remarkably, only a limited number of solutions have incorporated lubricated contacts subjected to rolling, sliding and normal approach and the separation of surfaces, with most solutions being provided by Ramsey and his co-workers [147-152].

\section{Concluding Remarks}

Ramsey Gohar provided sustained contributions to the fundamental understanding and applications of EHL, throughout a research career spanning nearly 60 years. Here, only a sample of his work is cited within the context of developments in tribology during his career. His pioneering research included the development of precise methods of observation and measurement, as well as the establishment of fundamental theories and methods of solution. He studied many applications of contact mechanics and elastohydrodynamics to bearings, gears and other highly loaded concentrated contacts. The breadth of his research extends to the integration of dynamics and tribology, as highlighted in his books [72,73], aimed at the broad audience of undergraduates, practicing engineers, and both budding and established researchers. He will be remembered for his outstanding contributions to the field of tribology as well as for his abilities as a caring educator.

Author Contributions: Conceptualization, P.M.J.-R., G.K., R.A. and H.R.; Investigation, P.M.J.-R., Original draft, P.M.J.-R., H.R., Editing, P.M.J.-R., G.K., R.A. and H.R. All authors have read and agreed to the published version of the manuscript.

Funding: This research received no external funding. 
Institutional Review Board Statement: Not applicable.

Informed Consent Statement: Not applicable.

Data Availability Statement: Not applicable.

Conflicts of Interest: The authors declare no conflict of interest.

\section{References}

1. Gohar, R. The Lubrication of Spheres. Master's Thesis, Imperial College of Science and Technology, University of London, London, UK, 1959.

2. Reynolds, O. On the theory of lubrication and its application to Mr. Beauchamp Tower's experiments, including an experimental determination of the viscosity of olive oil. Phil. Trans. R. Soc. Lond. 1886, 177, 157-234.

3. Martin, H.M. Lubrication of gear teeth. Engineering 1916, 102, 119.

4. Peppler, W. Untersuchungen Uber Die Druckubertragung Bei Belasteten und Geschmierten Umlaufenden Achsparallelen Zylindern; Maschinenelemente-Tagung: Aachen, Germany, 1935.

5. Meldahl, A. Contribution to the theory of the lubrication of gears and the stressing of the lubricated flanks of gear teeth. Brown Boveri Rev. 1941, 28, 374-382.

6. Ertel, A.M. Hydrodynamic lubrication based on new principles. Akad. Nauk. SSSR Prikadnaya Mathematica i Mekkanika 1939, 3 , 41-52.

7. Grubin, A.N. Contact Stresses in Toothed Gears and Worm Gears. In Book 30 CSRI for Technology and Mechanical Engineering; CSRI (Central Scientific Research Institute): Moscow, Russia, 1949.

8. Grubin, A.N.; Vinogradova, I.E. Fundamentals of the hydrodynamic theory of lubrication of heavily loaded cylindrical surfaces. In Book 30 CSRI for Technology and Mechanical Engineering; Translation No. 337; CSRI (Central Scientific Research Institute): Moscow, Russia, 1949.

9. Gohar, R. Oil Film under Elasto-Hydrodynamic Conditions. Ph.D. Thesis, Imperial College of Science and Technology, University of London, London, UK, 1965.

10. Petrusevich, A.I. Fundamental conclusions from the contact-hydrodynamic theory of lubrication. Izv. Akad. Nauk. SSSR OTN 1951, 2, 209-223.

11. Dowson, D.; Higginson, G.R. A numerical solution to the elastohydrodynamic problem. J. Mech. Eng. Sci. 1959, 1, 6-15. [CrossRef]

12. Crook, A.W. The lubrication of rollers, II-Film thickness with respect to viscosity and speed. Philos. Trans. R. Soc. 1961, A254, 223-236.

13. Sibley, L.B.; Orcutt, F.K. Elasto-hydrodynamic lubrication of rolling-contact surfaces. Trans. ASLE 1961, 4, 234-249. [CrossRef]

14. Archard, J.F.; Kirk, M.T. Lubrication at point contacts. Proc. R. Soc. 1962, 261, 532-550.

15. Archard, J.F.; Cowking, E.W. Paper 3: Elastohydrodynamic Lubrication at Point Contacts. Proc. Inst. Mech. Eng. 1965, 180, 47-56. [CrossRef]

16. Sadeghi, F. Elastohydrodynamic lubrication. In Tribology and Dynamics of Engine and Powertrain; Woodhead Publications: Cambridge, UK, 2010; pp. 171-226.

17. Morris, N.J.; Johns-Rahnejat, P.M.; Rahnejat, H. Tribology and Dowson. Lubricants 2020, 8, 63. [CrossRef]

18. Schulz, L.G. An interferometric method for accurate thickness measurements of thin evaporated films. JOSA 1950, 40, 690-692. [CrossRef]

19. Tolansky, S. The measurement of thin film thickness by interferometry. JOSA 1951, 41, 425-426. [CrossRef]

20. Kirk, M.T. Hydrodynamic lubrication of 'perspex'. Nature 1962, 194, 965-966. [CrossRef]

21. Gohar, R.; Cameron, A. Optical measurement of oil film thickness under elasto-hydrodynamic lubrication. Nature 1963, 200, 458-459. [CrossRef]

22. Gohar, R. Oil film thickness and friction in EHD point contacts. J. Lubr. Tech. 1971, 93, 371-382. [CrossRef]

23. Gentle, C.R.; Cameron, A. Optical elastohydrodynamics at extreme pressures. Nature 1973, 246, 478-479. [CrossRef]

24. Thorp, N.; Gohar, R. Oil film thickness and shape for a ball sliding in a grooved raceway. Trans. ASME J. Tribol. 1972, 94, 199-208. [CrossRef]

25. Cann, P.; Hutchinson, J.; Spikes, H.A. The development of a spacer layer imaging method (SLIM) for EHL contacts. Trib. Trans. 1996, 39, 915-921. [CrossRef]

26. Gohar, R.; Cameron, A. The mapping of elastohydrodynamic contacts. Trans. ASLE 1967, 10, 215-225. [CrossRef]

27. Bahadoran, H.; Gohar, R. Oil film thickness in lightly-loaded roller bearings. J. Mech. Eng. Sci. 1974, 16, 386-390. [CrossRef]

28. Wymer, D.G.; Cameron, A. Elastohydrodynamic lubrication of a line contact. Proc. Inst. Mech. Eng. 1974, 188, 221-238. [CrossRef]

29. Park, T.J. Effect of roller profile and misalignment in EHL of finite line contacts. In Engineering Systems Design and Analysis; ASME: New York, NY, USA, 2010; pp. 395-401.

30. Omasta, M.; Adam, J.; Sperka, P.; Krupka, I.; Hartl, M. On the temperature and lubricant film thickness distribution in EHL contacts with arbitrary entrainment. Lubricants 2018, 6, 101. [CrossRef]

31. Ciulli, E.; Pugliese, G.; Fazzolari, F. Film thickness and shape evaluation in a cam-follower line contact with digital image processing. Lubricants 2019, 7, 29. [CrossRef] 
32. Krupka, I.; Hartl, M.; Matsuda, K.; Nishikawa, H.; Wang, J.; Guo, F.; Yang, P.; Kaneta, M. Deformation of Rough Surfaces in Point EHL Contacts. Tribol. Lett. 2019, 67, 33. [CrossRef]

33. Bridgman, P.W. Physics of High Pressure; Bell \& Sons Ltd.: London, UK, 1958.

34. Kannel, J.W.; Bell, J.C.; Allen, C.M. Methods for determining pressure distributions in lubricated rolling contact. Trans. ASLE 1965, 8, 250-270. [CrossRef]

35. Kannel, J.W. Paper 11: Measurements of Pressures in Rolling Contact. Proc. Inst. Mech. Eng. 1965, 180, 135-146. [CrossRef]

36. Kannel, J.W. Comparison between predicted and measured axial pressure distribution between cylinders. J. Lubr. Tech. 1974, 96, 508-514. [CrossRef]

37. Hamilton, G.M.; Moore, S. Deformation and pressure in an elastohydrodynamic contact. Proc. R. Soc. 1971, 322, 313-330.

38. Safa, M.M.A.; Leather, J.A.; Anderson, J.C. Thin film microtransducers for elastohydrodynamic lubrication studies. Thin Solid Films 1979, 64, 257-262. [CrossRef]

39. Safa, M.M.A. Elastohydrodynamic Studies Using Thin Film Transducers. Ph.D. Thesis, Imoerial College of Science \& Technology, University of London, London, UK, 1982.

40. Safa, M.M.A.; Anderson, J.C.; Leather, J.A. Transducers for pressure, temperature and oil film thickness measurement in bearings. Sens. Actuators 1982, 3, 119-128. [CrossRef]

41. Gohar, R.; Safa, M.M.A. Measurement of contact pressure under elastohydrodynamic lubrication conditions. In Tribology and Dynamics of Engine and Powertrain; Woodhead Publishing: Cambridge, UK, 2010; pp. 222-245.

42. Johns-Rahnejat, P.M. Pressure and Stress Distribution under Elastohydrodynamic Point Contacts. Ph.D. Thesis, Imperial College of Science and Technology, University of London, London, UK, 1988.

43. Johns-Rahnejat, P.M.; Gohar, R. Measuring contact pressure distributions under elastohydrodynamic point contacts. Tribotest 1994, 1, 33-53. [CrossRef]

44. Safa, M.M.A.; Gohar, R. Pressure distribution under a ball impacting a thin lubricant layer. J. Tribol. 1986, 108, 372-376. [CrossRef]

45. Mohammadpour, M.; Johns-Rahnejat, P.M.; Rahnejat, H.; Gohar, R. Boundary conditions for elastohydrodynamics of circular point contacts. Tribol. Lett. 2014, 53, 107-118. [CrossRef]

46. Cameron, A.; Gohar, R. Theoretical and experimental studies of the oil film in lubricated point contact. Proc. R. Soc. Series A Math. Phys. Sci. 1966, 291, 520-536.

47. Hamrock, B.J.; Dowson, D. Isothermal elastohydrodynamic lubrication of point contacts: Part 1-Theoretical formulation. J. Lubr. Tech. 1976, 98, 223-228. [CrossRef]

48. Hamrock, B.J.; Dowson, D. Isothermal elastohydrodynamic lubrication of point contacts: Part II—Ellipticity parameter results. J. Lubr. Tech. 1976, 98, 375-381. [CrossRef]

49. Hamrock, B.J.; Dowson, D. Isothermal elastohydrodynamic lubrication of point contacts: Part III-fully flooded results. J. Lubr. Tech. 1977, 99, 264-275. [CrossRef]

50. Hamrock, B.J.; Dowson, D. Isothermal elastohydrodynamic lubrication of point contacts: Part IV—starvation results. J. Lubr. Tech. 1977, 99, 15-23. [CrossRef]

51. Vakilzadeh, A.; Gohar, R. Oil-film starvation in elastohydrodynamic circular contacts. J. Mech. Eng. Sci. 1977, 19, 22-29. [CrossRef]

52. Mostofi, A.; Gohar, R. Oil film thickness and pressure distribution in elastohydrodynamic point contacts. J. Mech. Eng. Sci. 1982, 24, 173-182. [CrossRef]

53. Chittenden, R.J.; Dowson, D.; Dunn, J.F.; Taylor, C.M. A theoretical analysis of the isothermal elastohydrodynamic lubrication of concentrated contacts. I. Direction of lubricant entrainment coincident with the major axis of the Hertzian contact ellipse. Proc. R. Soc. 1985, 397, 245-269.

54. Chittenden, R.J.; Dowson, D.; Dunn, J.F.; Taylor, C.M. Elastohydrodynamic lubrication of concentrated contacts—Part 2: General case, with lubricant entrainment along either principal axis of the Hertzian contact ellipse. Proc. R. Soc. 1985, 397, 271-294.

55. Evans, H.P.; Snidle, R.W. Analysis of elastohydrodynamic lubrication of elliptical contacts with rolling along the major axis. $J$. Mech. Eng. Sci. 1983, 197, 209-211. [CrossRef]

56. Evans, H.P.; Snidle, R.W. The elastohydrodynamic lubrication of point contacts at heavy loads. Proc. R. Soc. 1982, 382, 183-199.

57. Thorp, N.; Gohar, R. Elastohydrodynamic sliding friction in a low modulus point contact. J. Mech. Eng. Sci. 1973, 15, 109-113. [CrossRef]

58. Hamrock, B.J.; Dowson, D. Elastohydrodynamic lubrication of elliptical contacts for materials of low elastic modulus I-Fully flooded conjunction. J. Lubr. Tech. 1978, 100, 236-245. [CrossRef]

59. Biswas, S.; Snidle, R.W. Elastohydrodynamic lubrication of spherical surfaces of low elastic modulus. J. Lubr. Tech. 1976, 98, 524-529. [CrossRef]

60. Karami, G.; Evans, H.P.; Snidle, R.W. Paper VIII (i) Elastohydrodynamic lubrication of grooved rollers. In Tribology Series; Elsevier: Amsterdam, The Netherlands, 1987; Volume 11, pp. 239-246.

61. Karami, G.; Evans, H.P.; Snidle, R.W. Elastohydrodynamic lubrication of circumferentially finished rollers having sinusoidal roughness. J. Mech. Eng. Sci. 1987, 201, 29-36. [CrossRef]

62. Ehret, P.; Dowson, D.; Taylor, C.M. Waviness orientation in EHL point contact. In Tribology Series; Elsevier: Amsterdam, The Netherlands, 1996; Volume 31, pp. 235-244.

63. Lubrecht, A.A.; Graille, D.; Venner, C.H.; Greenwood, J.A. Waviness amplitude reduction in EHL line contacts under rollingsliding. J. Tribol. 1998, 120, 705-709. [CrossRef] 
64. Lubrecht, A.A.; Venner, C.H. Elastohydrodynamic lubrication of rough surfaces. J. Eng. Trib. 1999, 213, 397-404. [CrossRef]

65. Ehret, P.; Dowson, D.; Taylor, C.M. Transient EHL solutions with interfacial slip. J. Tribol. 1999, 121, 703-710. [CrossRef]

66. Jalali-Vahid, D.; Rahnejat, H.; Gohar, R.; Jin, Z.M. Prediction of oil-film thickness and shape in elliptical point contacts under combined rolling and sliding motion. Proc. Inst. Mech. Eng. Part J J. Eng. Tribol. 2000, 214, 427-437. [CrossRef]

67. Vahid, D.J.; Rahnejat, H.; Jin, Z.M.; Downson, D. Transient analysis of isothermal elastohydrodynamic circular point contacts. Proc. Inst. Mech. Eng. Part C J. Mech. Eng. Sci. 2001, 215, 1159-1172. [CrossRef]

68. Venner, C.H. Higher-order multilevel solvers for the EHL line and point contact problem. J. Tribol. 1994, 116, 741-750. [CrossRef]

69. Jalali-Vahid, D.; Rahnejat, H.; Gohar, R.; Jin, Z.M. Comparison between experiments and numerical solutions for isothermal elastohydrodynamic point contacts. J. Phys. D Appl. Phys. 1998, 31, 2725. [CrossRef]

70. Venner, C.H.; Lubrecht, A.A. Multigrid techniques: A fast and efficient method for the numerical simulation of elastohydrodynamically lubricated point contact problems. Proc. Inst. Mech. Eng. Part J J. Eng. Trib. 2000, 214, 43-62. [CrossRef]

71. Wang, J.; Qu, S.; Yang, P. Simplified multigrid technique for the numerical solution to the steady-state and transient EHL line contacts and the arbitrary entrainment EHL point contacts. Tribol. Int. 2001, 34, 191-202. [CrossRef]

72. Gohar, R. Elastohydrodynamics; World Scientific: London, UK, 2001.

73. Gohar, R.; Rahnejat, H. Fundamentals of Tribology; Imperial College Press: London, UK, 2008.

74. Sivayogan, G.; Rahmani, R.; Rahnejat, H. Transient analysis of isothermal elastohydrodynamic point contacts under complex kinematics of combined rolling, spinning and normal approach. Lubricants 2020, 8, 81. [CrossRef]

75. Al-Samieh, M.F.; Rahnejat, H. Physics of lubricated impact of a sphere on a plate in a narrow continuum to gaps of molecular dimensions. J. Phys. D Appl. Phys. 2002, 35, 2311. [CrossRef]

76. Liu, X.; Jiang, M.; Yang, P.; Kaneta, M. Non-Newtonian thermal analyses of point EHL contacts using the Eyring model. J. Tribol. 2005, 127, 70-81. [CrossRef]

77. Spikes, H.A. Sixty years of EHL. Lubr. Sci. 2006, 18, 265-291. [CrossRef]

78. Kumar, P.; Khonsari, M.M. On the role of lubricant rheology and piezo-viscous properties in line and point contact EHL. Tribol. Int. 2009, 42, 1522-1530. [CrossRef]

79. Carli, M.; Sharif, K.J.; Ciulli, E.; Evans, H.P.; Snidle, R.W. Thermal point contact EHL analysis of rolling/sliding contacts with experimental comparison showing anomalous film shapes. Tribol. Int. 2009, 42, 517-525. [CrossRef]

80. Karthikeyan, B.K.; Teodorescu, M.; Rahnejat, H.; Rothberg, S.J. Thermoelastohydrodynamics of grease-lubricated concentrated point contacts. Proc. Inst. Mech. Eng. Part C J. Mech. Eng. Sci. 2010, 224, 683-695. [CrossRef]

81. Li, S.; Kahraman, A. A transient mixed elastohydrodynamic lubrication model for spur gear pairs. J. Tribol. 2010, $132,011501$. [CrossRef]

82. Habchi, W.; Bair, S.; Qureshi, F.; Covitch, M. A film thickness correction formula for double-Newtonian shear-thinning in rolling EHL circular contacts. Tribol. Lett. 2013, 50, 59-66. [CrossRef]

83. Paouris, L.; Rahmani, R.; Theodossiades, S.; Rahnejat, H.; Hunt, G.; Barton, W. An analytical approach for prediction of elastohydrodynamic friction with inlet shear heating and starvation. Tribol. Lett. 2016, 64, 10. [CrossRef]

84. Mohammadpour, M.; Theodossiades, S.; Rahnejat, H.; Dowson, D. Non-Newtonian mixed thermo-elastohydrodynamics of hypoid gear pairs. Proc. Inst. Mech. Eng. Part J J. Eng. Trib. 2018, 232, 1105-1125. [CrossRef]

85. Sivayogan, G.; Rahmani, R.; Rahnejat, H. Lubricated loaded tooth contact analysis and non-Newtonian thermoelastohydrodynamics of high-performance spur gear transmission systems. Lubricants 2020, 8, 20. [CrossRef]

86. Hajishafiee, A.; Kadiric, A.; Ioannides, S.; Dini, D. A coupled finite-volume CFD solver for two-dimensional elasto-hydrodynamic lubrication problems with particular application to rolling element bearings. Tribol. Int. 2017, 109, 258-273. [CrossRef]

87. Singh, K.; Sadeghi, F.; Russell, T.; Lorenz, S.J.; Peterson, W.; Villarreal, J.; Jinmon, T. Fluid-Structure Interaction Modeling of Elastohydrodynamically Lubricated Line Contacts. J. Tribol. 2021, 143, 091602. [CrossRef]

88. Zhao, Y.; Wong, P.L.; Guo, L. Linear complementarity solution of 2D boundary slip EHL contact. Tribol. Int. 2020, 145, 106178. [CrossRef]

89. Peterson, W.; Russell, T.; Sadeghi, F.; Berhan, M.T.; Stacke, L.E.; Ståhl, J. A CFD investigation of lubricant flow in deep groove ball bearings. Tribol. Int. 2021, 154, 106735. [CrossRef]

90. Chan, R.T.; Martinez-Botas, R.F.; Gohar, R. Isoviscous flow past a rigid sphere partially immersed in a thin oil film. Lubr. Sci. 2007, 19, 197-212. [CrossRef]

91. Hertz, H. Uber die Berührung fester elastischer Körper. J. Für Die Reine Und Angew. Math. 1882, 92, $156-171$.

92. Harris, T.A. Rolling Bearing Analysis; Wiley: Hoboken, NJ, USA, 1966.

93. Palmgren, A. Ball and Roller Bearing Engineering; SKF Industries Inc.: Philadelphia, PA, USA, 1959.

94. Lundberg, G. Elastic Contact between Two Semi-infinite Bodies. Forsch. Auf Den Geb. Ing. 1961, 10, $165-174$.

95. Kannel, J.W.; Walowit, J.A.; Bell, J.C.; Allen, C.M. The Determination of Stresses in Rolling-Contact Elements. ASME J. Lubn. Tech. 1967, 89, 453-463. [CrossRef]

96. Hartnell, M.J. The Analysis of Contact Stresses in Rolling Element Bearings. J. Lubr. Tech. 1979, 101, 105-109. [CrossRef]

97. Nikpur, K.; Gohar, R. Deflexion of a roller compressed between platens. Tribol. Int. 1975, 8, 2-8. [CrossRef]

98. Heydari, M.; Gohar, R. The Influence of the Axial Profile on Pressure Distribution in Radially Loaded Rollers. J. Mech. Eng. Sci. 1979, 21, 381-388. [CrossRef]

99. Mostofi, A.; Gohar, R. Pressure distribution between closely contacting surfaces. J. Mech. Eng. Sci. 1980, 22, 251-259. [CrossRef] 
100. Mostofi, A.; Gohar, R. The use of various types of pressure element in some elastic contact problems. Proc. Inst. Mech. Eng. Part C J. Mech. Eng. Sci. 1984, 198, 189-196. [CrossRef]

101. Johns, P.M.; Gohar, R. Roller bearings under radial and eccentric loads. Tribol. Int. 1981, 14, 131-136. [CrossRef]

102. So, H.; Gohar, R. The elastic distortion of rollers under combined radial and thrust loads. J. Lubr. Tech. 1983, $105,189-197$. [CrossRef]

103. Nikpur, K.; Gohar, R. Profiled taper rollers. Tribol. Int. 1975, 8, 203-208.

104. Rahnejat, H.; Gohar, R. Design of profiled taper roller bearings. Tribol. Int. 1979, 12, 269-275. [CrossRef]

105. Rahnejat, H.; Johns-Rahnejat, P.M.; Teodorescu, M.; Votsios, V.; Kushwaha, M. A review of some tribo-dynamics phenomena from micro-to nano-scale conjunctions. Tribol. Int. 2009, 42, 1531-1541. [CrossRef]

106. Gohar, R.; Thorp, N. Keeping the bearings rolling (ball and roller bearing fabrication and performance). New Sci. 1977, 74, 124-126.

107. Fergusson, B.; Ross, D.; Ismail, M.A.; Gohar, R. Report 13: Pressure Developed in the Lubricant Film between Two Contacting Surfaces in Relative Motion. Proc. Inst. Mech. Eng. 1967, 182, 79-82. [CrossRef]

108. Bahadoran, H.; Gohar, R. Research note: End closure in elastohydrodynamic line contact. Proc. Inst. Mech. Eng. J. Mech. Eng. Sci. 1974, 16, 276-278. [CrossRef]

109. Mostofi, A.; Gohar, R. Elastohydrodynamic lubrication of finite line contacts. J. Lubr. Tech. 1983, 105, 598-604. [CrossRef]

110. Kushwaha, M.; Rahnejat, H.; Gohar, R. Aligned and misaligned contacts of rollers to races in elastohydrodynamic finite line conjunctions. Proc. Inst. Mech. Eng. Part C J. Mech. Eng. Sci. 2002, 216, 1051-1070. [CrossRef]

111. Kushwaha, M.; Rahnejat, H. Transient elastohydrodynamic lubrication of finite line conjunction of cam to follower concentrated contact. J. Phys. D Appl. Phys. 2002, 35, 2872. [CrossRef]

112. Kushwaha, M.; Rahnejat, H. Transient concentrated finite line roller-to-race contact under combined entraining, tilting and squeeze film motions. J. Phys. D Appl. Phys. 2004, 37, 2018. [CrossRef]

113. Sun, H.; Chen, X. Thermal EHL analysis of cylindrical roller under heavy load. In IUTAM Symposium on Elastohydrodynamics and Micro-Elastohydrodynamics; Springer: Dordrecht, The Netherlands, 2006; pp. 107-120.

114. Liu, X.; Yang, P. Numerical analysis of the oil-supply condition in isothermal elastohydrodynamic lubrication of finite line contacts. Trib. Lett. 2010, 38, 115-124. [CrossRef]

115. Mihailidis, A.; Agouridas, K.; Panagiotidis, K. Non-Newtonian starved thermal-elastohydrodynamic lubrication of finite line contacts. Trib. Trans. 2013, 56, 88-100. [CrossRef]

116. Hultqvist, T.; Shirzadegan, M.; Vrcek, A.; Baubet, Y.; Prakash, B.; Marklund, P.; Larsson, R. Elastohydrodynamic lubrication for the finite line contact under transient loading conditions. Tribol. Int. 2018, 127, 489-499. [CrossRef]

117. Tsuha, N.A.; Cavalca, K.L. Finite line contact stiffness under elastohydrodynamic lubrication considering linear and nonlinear force models. Tribol. Int. 2020, 146, 106219. [CrossRef]

118. Huber, M.T.; Fuchs, S. Spannungverleitung bei der beruhrung zweier elastischer zylinder. Phys. Z. 1914, 15, $298-303$.

119. Ioannides, E.; Harris, T.A. A new fatigue life model for rolling bearings. J. Tribol. 1985, 107, 367-378. [CrossRef]

120. Lyman, J. Reversing normal strains produced by rolling contact load. J. Lubr. Tech. 1967, 89, 76-80. [CrossRef]

121. Poritsky, H. Stresses and deflections of cylindrical bodies in contact with application to contact of gears and locomotive wheels. $J$. Appl. Mech. 1950, 18, 191-201. [CrossRef]

122. Johns-Rahnejat, P.M.; Gohar, R. Point contact elastohydrodynamic pressure distribution and sub-surface stress field. In Proceedings of the Tri-annual Conference on Multi-body Dynamics: Monitoring and Simulation Techniques, Bradford, UK, 25-27 March 1997; pp. 161-179.

123. Johnson, K.L. One hundred years of Hertz contact. Proc. Inst. Mech. Eng. 1982, 196, 363-378. [CrossRef]

124. Johnson, K.L. Contact Mechanics; Cambridge University Press: Cambridge, UK, 1987.

125. Johns-Rahnejat, P.M.; Dolatabadi, N.; Rahnejat, H. Analytical elastostatic contact mechanics of highly-loaded contacts of varying conformity. Lubricants 2020, 8, 89. [CrossRef]

126. Muskhelishvili, N.I. Some Basic Problems of the Mathematical Theory of Elasticity; Noordhoff: Groningen, The Netherlands, 1963; p. 17404.

127. Jaffar, M.J. Asymptotic behaviour of thin elastic layers bonded and unbonded to a rigid foundation. Int. J. Mech. Sci. 1989, 31, 229. [CrossRef]

128. Barber, J.R. Contact problems for the thin elastic layer. Int. J. Mech. Sci. 1990, 32, 129-132. [CrossRef]

129. Naghieh, G.R.; Rahnejat, H.; Jin, Z.M. Characteristics of frictionless contact of bonded elastic and viscoelastic layered solids. Wear 1998, 232, 243-249. [CrossRef]

130. Teodorescu, M.; Rahnejat, H.; Gohar, R.; Dowson, D. Harmonic decomposition analysis of contact mechanics of bonded layered elastic solids. Appl. Math. Model. 2009, 33, 467-485. [CrossRef]

131. Teodorescu, M.; Votsios, V.; Johns-Rahnejat, P.M.; Rahnejat, H. Fundamentals of impact dynamics of semi-infinite and layered solids. In Tribology and Dynamics of Engine and Powertrain; Woodhead Publishing: Cambridge, UK, 2010; pp. 105-132.

132. Mostofi, A. Oil Film Thickness and Pressure Distribution in Elastohydrodynamic Elliptical Contacts. Ph.D. Thesis, Imperial College of Science and Technology, University of London, London, UK, 1981.

133. Rahnejat, H. Influence of Vibrations on the Oil Film in Concentrated Contacts. Ph.D. Thesis, Imperial College of Science and Technology, University of London, London, UK, 1984. 
134. Rahnejat, H.; Gohar, R. The vibrations of radial ball bearings. Proc. Inst. Mech. Eng. Part C J. Mech. Eng. Sci. 1985, 199, 181-193. [CrossRef]

135. Newmark, N.M. A method of computation for structural dynamics. J. Eng. Mech. Div. 1959, 85, 67-94. [CrossRef]

136. Rahnejat, H. Computational modelling of problems in contact dynamics. Eng. Anal. 1985, 2, 192-197. [CrossRef]

137. Gupta, P.K. Dynamics of rolling-element bearings-Part I: Cylindrical roller bearing analysis. J. Lubr. Tech. 1979, 101, $293-302$. [CrossRef]

138. Gupta, P.K. Dynamics of rolling-element bearings-Part III: Ball bearing analysis. J. Lubr. Tech. 1979, 101, 312-318. [CrossRef]

139. Yhland, E. A linear theory of vibrations caused by ball bearings with form errors operating at moderate speed. J. Tribol. 1992, 114, 348-359. [CrossRef]

140. Fukata, S.; Gad, E.H.; Kondou, T.; Ayabe, T.; Tamura, H. On the radial vibration of ball bearings: Computer simulation. Bull. JSME 1985, 28, 899-904. [CrossRef]

141. Harsha, S.P. The effect of ball size variation on nonlinear vibrations associated with ball bearings. Proc. Inst. Mech. Eng. Part K J. Multi-Body Dyn. 2004, 218, 191-210. [CrossRef]

142. Matsubara, M.; Rahnejat, H.; Gohar, R. Computational modelling of precision spindles supported by ball bearings. Int. J. Mach. Tools Manuf. 1988, 28, 429-442. [CrossRef]

143. Gohar, R.; Akturk, N. Vibrations associated with ball bearings. IMechE Conf. Trans. 1998, 13, $43-64$.

144. Akturk, N.; Gohar, R. The effect of ball size variation on vibrations associated with ball-bearings. Proc. Inst. Mech. Eng. Part J J. Eng. Tribol. 1998, 212, 101-110. [CrossRef]

145. Rahman, A.K.; Aini, R.; Gohar, R. On the performance of multi-support spindle-bearing assemblies. Proc. Inst. Mech. Eng. Part K J. Multi-Body Dyn. 2002, 216, 117-132. [CrossRef]

146. Rahman, A.K.; Aini, R.; Gohar, R. On the effects of bearing settings on the dynamic performance of a three-bearing machine tool spindle assembly. Proc. Inst. Mech. Eng. Part K J. Multi-Body Dyn. 2002, 216, 133-141. [CrossRef]

147. Aini, R.; Rahnejat, H.; Gohar, R. A five degrees of freedom analysis of vibrations in precision spindles. Int. J. Mach. Tools Manuf. 1990, 30, 1-8. [CrossRef]

148. Stacke, L.E.; Fritzson, D.; Nordling, P. BEAST_A rolling bearing simulation tool. Proc. Inst. Mech. Eng. Part K J. Multi-Body Dyn. 1999, 213, 63-71. [CrossRef]

149. Aini, R.; Rahnejat, H.; Gohar, R. Vibration modeling of rotating spindles supported by lubricated bearings. J. Tribol. 2002, 124, 158-165. [CrossRef]

150. Savalia, R.; Ghosh, M.K.; Pandey, R.K. Vibration analysis of lubricated angular contact ball bearing of rigid rotor considering waviness of ball and races. Tribol. Online 2008, 3, 322-327. [CrossRef]

151. Babu, C.K.; Tandon, N.; Pandey, R.K. Vibration modeling of a rigid rotor supported on the lubricated angular contact ball bearings considering six degrees of freedom and waviness on balls and races. J. Vib. Acoust. 2012, 134, 011006. [CrossRef]

152. Mohammadpour, M.; Johns-Rahnejat, P.M.; Rahnejat, H. Roller bearing dynamics under transient thermal-mixed non-Newtonian elastohydrodynamic regime of lubrication. Proc. Inst. Mech. Eng. Part K J. Multi-Body Dyn. 2015, 229, 407-423. [CrossRef] 